\title{
Impacts of Tangible And Intangible Asset Investment On Value of Manufacturing Companies Listed On The Indonesia Stock Exchange
}

\author{
Mustaruddin Saleh \\ Department of Management, \\ Faculty of Economics and Business (FEB), \\ Tanjungpura University, \\ Jalan. Prof. Dr. H. Hadari Nawawi, \\ Pontianak, INDONESIA
}

\begin{abstract}
This paper was conducted to examine the effect of tangible and intangible assets investments on the value of manufacturing companies listed on the Indonesia Stock Exchange. 51 of 143 companies were selected using the purposive sampling method with 255 observations during the period 2012-2016. This research uses three regression models for panel data estimation, namely, the common effect model (CEM), fixed effect model (FEM), and random effect model (REM). Measurement of firm value is done using 3 alternative dependent variables, which are: return on asset (ROA), price to book value (PBV), and stock return ( $R t)$. The result of the analysis showed that FEM is more precise in predicting the influence of independent variable to dependent variable, because the probability value of Cho-test and Hausman test is smaller than $\alpha=$ 0.05. The result of data analysis using FEM showed that from the two independent variables used, only the tangible asset variable and the other three control variables, namely, current ratio (CR), earnings per share (EPS), and net profit margin (NPM) have significant effect on firm value. The results of study is in line with previous research (Cao, 2015; Berk, et al., 1999; and Carlson, et al., 2006), which reported that investment in tangible assets negatively affected the short-term return of the company. This supports the fact that the aim of investors in the Indonesian capital market are for profit taking in short-term oriented.
\end{abstract}

Keywords: tangible assets, intangible assets, investment, firm value, profit taking.

\section{INTRODUCTION}

In a bid to sustain the continuity of the business, it is necessary for the company to make and increase its investment in the capital expenditure. This action is in line with the rapidly evolving technology developments, thus, making the use of existing assets to be increasingly short. Various considerations of companies investing in capital expenditure is to maintain superiority and improve performance of the company. Companies with large financial resources trying to simultaneously invest in tangible and intangible assets of various forms. Both types of tangible and intangible asset investments necessitate cost adjustment and accumulated investment amounts on the assets that will increase investment productivity on intangible assets, known as "investment-specific technological change (ISTC)" effect (Li and Liu, 2012), especially investments that will generate and commercialize future innovation potentials (Furman, Porter, and Stern, 2002; Kumar and Li, 2016). Engaging in existing and new product research and development activities helps to create growth opportunities, since innovation-related activities are often the source of new ideas and opportunities for companies to survive under global competition. 
An indication of capital expenditures in public companies that exist in Indonesia has shown significant growth, this is seen with the increasing amount of non-current assets of the company. However, when investment activity leading to innovation investment is limited, it is illustrated by the lack of information on the amount of investment published by the company. The low level of investment in this innovative capacity, possibly in addition to requiring great investment value, is also the rapidly achieving age of technology industry, so only companies with relatively large financial resource capabilities invest in such innovations. The results of the empirical studies show that there is a negative relationship between capital expenditure and the expected short-term return (Cao, 2015; Berk, Green, and Naik, 1999; Carlson, Fisher, and Giammarino, 2006). However, other studies have shown that there is a significant positive effect between research and development (R\&D) investment on cumulative returns (Kumar and Li, 2016, Anderson and Garcia-Feijoo, 2006), because by investing, it can increase the expected revenue through high quality improvement of products when innovation is made.

This research was conducted due to the limited number of study on the effects of tangible and intangible assets investments as it affects the value of public companies in Indonesia. An important implication of this research model is that the impact of intangible asset investment capacity on future corporate value depends on how uncertainties in the investment choice is overcome. In particular, the effect is generally ambiguous before innovation is made and yielded, but it becomes unambiguously positive after choice is made, provided there is no increase in revenues from investment especially for R\&D (Kumar and Li, 2016). For testing the predicted model, the author uses the investment capacity of intangible assets conducted by the company. Particularly in R\&D being undertaken by the company, it can be viewed as a driving factor for innovation (Rogers, 1998).This study primarily uses growth of total fixed assets and investment in intangible assets, which is a gross measure of capital investment (Kumar and Li, 2016).

The empirical study conducted by Kumar and Li (2016) reported that in large firms, there is strong evidence that there is no significant effect of asset growth on cumulative returns in the first five years,which becomes significantly positive after the sixth year. The results of their empirical study also found that there is no similar pattern in small companies. Furthermore, it was found that the company's innovative capacity showed that there is a high possibility of investment in the future, and investment in innovation capacity is positively influencing future profitability in firms with large capacity for innovation.

Referring to previous research, this research reports that examination influence of capital investment to company value is based on behavioral and agency-theory perspective. Research conducted by Titman, Wei, and Xie (2004) is contrary to that of Kumar and Li (2016), where the findings suggested that there is a negative relationship between capital investment and returns above normal, this is called an anomaly investment. In literature, it is explained that investors do not react to empire building by managers. On the contrary, the investment of innovation capacity can be attributed to empire building, it is also seen to predict a negative relationship between innovation capacity investment and stock return, especially for companies with large difference in investment policy. Meanwhile, Cao, Simin and Zhao (2008), using the Model of Galai and Masulis (1976) revealed that there is a positive relationship between growth options and idiosyncratic volatility (IVOL) and they suggested that firms with high debt ratios have higher incentives when taking on projects with high idiosyncratic risk because these risks are borne by the debt owner. This perspective also implies a negative relationship between investment and stock returns (Kumar and Li, 2016). 
Based on the exposure, it can be stated that the empirical study of issues related to the influence of tangible and intangible assets investments on value of the company is still limited, hence, this research was conducted to contribute to financial research on empirical test between capital investment, especially investment of both tangible and intangible assets to firm value on Indonesia Stock Exchange. The format of the research report is arranged in the format of five sub-sections. First on the background of research, secondly on literature review, followed by third section which is the research method and the fourth contains analysis of research results and closing with the fifth section, conclusion and research recommendations.

\section{Return and Investment Risk}

\section{LITERATURE REVIEW}

The investment objective for every investor is how to maximize return, without forgetting the investment risk factors that must be faced. Return is one of the factors that motivate investors to invest and is also a reward for the risk taking by investors. According to Reilly and Brown (2004: 4) investors invest funds from their savings and delay consumption in order to get a return on their investment. Investors will choose stocks that generate high returns, with a high level of risk too, and other stocks with low returns will have a lower risk as well.

The sources of investment returns consist of two main components, namely yield and capital gain (loss). Yield is a component of a return that reflects the cash flow or income derived periodically from an investment. While capital gains (loss) is the second component of the return, which is an increase or decrease of an asset, such as stock securities that can provide profit or loss to investors. Information which published by companies to help investors in making investment decisions. Signaling theory explains that dividend is a tool used to control the company's financial condition. The dividend payout is a signal to the investor, that the company is in good financial condition. Dividends do not directly impact stock prices, but it shows the impact of the company's prospects on the amount of dividends distributed. Stock prices tend to increase if there is an announcement of payments and dividend increases and vice versa, while stock prices will experience a decrease if there is a decrease in dividend payouts or no dividend at all. Investors who expect good profits from capital gains and dividends should be able to analyze what factors will affect the stock return change.

The risk of an investment is the possible difference between the actual return received and the expected return (Tandelilin, 2010). The greater the likelihood of the difference, the greater the investment risk. There are several sources of risk that can affect the amount of risk undertaken by an investment. Sources of such risks include interest rate risk, market risk, inflation risk, business risk, financial risk, liquidity risk, currency exchange risk, and state risk (Tandelilin, 2010). Changes in interest rates can affect the variability of return of an investment. Changes in interest rates can have a positive impact on stock prices when there is a decline in interest rates on the money market, while stock prices will decrease if there is an increase in the interest rates. The overall market fluctuations will affect the variablity of return of a stock. This is indicated by changes in the stock market index as a whole. Inflation risks can also affect the return of an investment in the stock market, rising inflation will result in lower public purchasing power, thus decreasing the investment demand in the stock market. Furthermore, risks associated with internal decisions such as business risk, financial and liquidity, will also affect the return of an investment.

Investment risk can be divided into two types, namely systematic risk and unsystematic risk. By diversifying investments, unsystematic risks or specific risks can be eliminated, whereas, systematic risk is a risk that cannot be eliminated by diversification, rather it is directly related 
to changes in the market as a whole. The risk is a possible deviation of the expected return, statistically, this risk can be represented by the size of the deviation or the spread of the data. Two commonly used deployment measures to represent it are the value of the variance and standard deviation. The greater the spread of the return distribution of an investment, the higher the investment risk level.

\section{Capital Budgeting}

Due to a company has limited resources, it is essential to invest in some projects and reject others. The process of capital budgeting serves to shape the future of companies, and variety of capital budgeting techniques have been proposed to assists managers who are engaged in this important palnning task (Zinkhan, 1994). The capital budgeting process includes, identification of potentiual projects, prediction of possible outcomes, project selection, financing and implementation of the chosen project, and monitoring project performance (Mukherjee and Henderson, 1987). According to Cheng (1994) that economic conditions should govern the capital budgeting decision, individual opinions and preferences project selection. The criterias of capital budgeting are contructed for local measures of project evaluation, these tools analyze at a static domestic level. Currently, by adopting simulation, the impacts of capital expenditures and critical interaction of resources in a dynamic global environment can be applied. Hardwere and software technology can provide a real opportunity for those making decisions regarding capital expenditures (Taylor III, 1998). The capital budgeting for foreign direct investment decisions may involve complexities not present in the local case these include economic, financial, political factors and related risks, e.g., foreign exchange risk and currencies movement. Therefore, the concept of cost of capital as a discount rate appropriately reflective of the degree of risk involved in a foreign direct investment (Stanley, 1990).

Tangible assets and intangible assets investments are referred to as capital budgeting and it is directly related to the level of risk faced by the company. In capital budgeting, firms still ignore the risk factor, for example, the company discounts the future cash flow and ignores the possible uncertainty surrounding the estimate. In capital budgeting, it is assumed that under various risk conditions, the company does not know which cash flow is actually derived from the new project. However, the company does have expectations about possible outcomes and the project owner or company can determine the magnitude of the probability of those results. In other words, even if the company does not know the cash flow derived from the receipt of a new project, it can formulate the probability distribution of the cash flow origin.

Investing in these two types of assets require a great investment value and goes a long way in determining the future of the company, but this does not always go the way it is planned (Keown et al., 2011). Here are some criteria used to assess the feasibility of investments made in capital budgeting: First criteria is Payback Period, this criterion is used to calculate the length of the refund rate invested from the capital budgeting project. This criterion measures how quickly the project will return the initial investment cost, this is related to free cash flow which measures the actual time of a benefit and not the accounting profit. The disadvantage of this method is that it ignores the time value by not discounting this free cashflow back to its present value. The acceptance criterion is if the payback period is faster or equal to the maximum period which is the economic life of the project. The disadvantage of this method is that it ignores the time value, and it is corrected by using the discounted payback period approach. The method of the payback period is discounted similar to the traditional payback method unless it uses free cash flow discounted while calculating the payback period. The acceptance criteria for this method is whether the discounted project return period will be faster or equal to the maximum discounted return period of the company. 
Second criteria is Net Present Value (NPV), NPV of an investment proposal equals the present value of free cash flows minus the value of the initial investment. The difference between the present value of annual free cash flows and the initial investment expenditures determines the net value of the acceptance of investment proposals in relation to the current dollar. If the present value difference in annual cash flows is greater than the initial investment value, then the NPV is positive, meaning that the proposed investment is received, but it is the opposite if the NPV is negative, that is, if the present value of annual cash flow is less than the initial investment value, then the project proposal is rejected. Third method is Internal Rate of Return (IRR), implies looking for a discount rate that equates the present value of the annual cash flow to the initial investment value of the project, so that the NPV becomes 0 . The decision criterion by this method is the project proposal accepted if its internal rate of return is equal to or greater than the required rate of return or its cost of capital. Conversely, the proposed project will be rejected if its internal rate of return is less than the capital cost. If the NPV is positive, then the IRR is greater than the desired rate of return, $k$. Accordingly, all disclaimed cash flow criteria will be consistent and provide similar acceptance-rejecting decisions.

Forth method is Modified Internal Rate of Return (MIRR), in each investment proposal, the criteria that are always used are NPV and IRR, because it produces the same result . However, if the project's annual cash flow is abnormal, that is, where over a period of time the project's life period occurs more than once there is a negative cash flow, so at the time of IRR calculation, there will be a double IRR, which will find more than one IRR to equalize the value now the annual cash flow of the project with its investment value. Thus, the weakness of the IRR method is improved upon by the term modifying the IRR (MIRR), that is, each cash inflows during the life of the project are re-invested at a certain interest rate until the end of the project. Thereafter, all cash flows at the end of the project life (terminal value) are summed and then the terminal value is discounted to equal the value of the project terminal which is equal to the value of the investment. The acceptance criterion by the MIRR method is that if the MIRR is greater than or equal to the required rate of return or capital cost, then the project is accepted, but if MIRR is less than the cost of capital, the project proposal is rejected. Fift method is Profitablity Index (PI), It is a comparison between the current yearly free value and investment spending. The NPV investment criterion provides a measure of the desired dollar or dollar absolute value of a proposed project, while the profitability index is a desirable relative measure. The criteria for acceptance of a proposed project with a PI method is if the PI score is greater than one and vice versa if the PI score is less than one .

\section{Previous Research}

Research on the impact of investment on capital expenditures, whether investments in tangible assets or in intangible assets toward the firm's value found different results. Generally, these findings have a positive impact on the value of the company. Research by Durnev, Morck and Yeung (2004) found that there is a positive relationship between the efficiency of the company's investment economy and the company's stock returns. The tests conducted by Cooper, Gulen and Schill (2008) using cross-section data revealed that the annual growth of firm assets is economically and statistically significant in predicting cross-section returns of the US corporate stocks. Polk and Sapienza (2009) who tested catering theory for observed a positive relationship between abnormal investment and stock return. They found that companies with abnormal investments had low stock returns and had higher relative premium prices as well as a higher possibility of abnormal returns.

McConnel and Muscarella (1985) who measured the impact of announcement of investment expenditure plan on real asset to the company's stock value showed that the announcement of 
increase (decrease) in fixed asset investment plan had a positive (negative) significant effect on excess stock return. More specifically, Treman (1986) tested the relationship between information conveyed by management and the level of capital investment undertaken. He revealed that the clearer the information conveyed about the investment project of the company, the more favored it was by investors, but the financial variable is still the dominant factor in the decision made by the investors. Furthermore, using the panel data methodology, Del Brio, De Miguel, and Pindado (2010) revealed that investments made could have long-term impact on Spanish companies, although no differences were found between companies that invested or divested.

Larger investment expenditures and increase in their abnormal investment are suitable for companies that follow low leverage periods, while new investments are financed from the issuance of new bonds. The impact of such funding flexibility is statistically significant and economically significant, and long-term performance of funding flexibility not only results in greater investment, but also better investment (Marchica and Mura, 2010). Further studies conducted by Lew (2015) revealed that each type of investment expenditures increase the value of a company, because of course, the company only chooses projects that have a positive NPV. However, if disaggregated by industry and market, it is revealed that some interaction variants do not have a positive effect on firm value. For example, the interaction variable of R3esearch and Development (R\&D) with Technology and Capital Expenditure with Technology resulted in a negative correlation to firm value in a high technology industry, but for interaction variable of advertising, total assets can increase company's value in the industry.

Some studies on the influence of intangible asset investment on the value of the company produced similar conclusions which have a positive effect on the value of the company. The study of the effect of intangible asset investment, particularly intellectual capital investment shows a positive influence on market value and financial performance of the company (Chen, Cheng, and Hwang (2005). When viewed from the information disclosure level of intangible assets investment, Gelb (2002) which made high investment expenditures on R\&D and advertising expenditures are likely to be more open, such as voluntarily publishing and establishing relationships with investors about the investment activity information. Garb discloses that firms that have high levels of investment in intangible assets significantly gained a higher rating level in the investor relations program or voluntary publications than the annual report.Other studies on investment in $R \& D$, revealed that the market responded positively to the mop investment expenditures on corporate research and development activities. It is used by investors as an indicator of profitability expectations and growth of the company (Johnson and Pazkerka, 1993; Chauvin and Hirschey, 1993).

The impact of the R\&D investment on the market value of US manufacturing companies and service industries revealed that R\&D investment in both industries positively affected the company's performance, despite the macroeconomic disruption (Ehie and Olibe, 2010). More specifically, the impact of R\&D investments, particularly investment in customer acquisition and service $(A \& S)$ in service companies revealed that customer acquisition costs and customer service costs investments are able to explain abnormal returns of service industry companies (Golec and Gupta, 2014) . Li, Liu and Xue (2014) using the structural estimation method revealed that investment in intangible assets provide a premium value and the relationship between $R \& D$ intensity and stock return is significantly better than the conventional $q$-theory. 


\section{Population and Sample}

\section{RESEARCH METHOD}

Population in this research is a public company in the manufacturing industry involving 143 companies listed in Bursa Efek Indonesia for a period of 5 years from 2012 till 2016. The sample of research was taken by purposive sampling. Of the total population, 51 companies were used for the research.

\section{Data analysis techniques}

Data analysis technique used in this research is the model Error Component Model (ECM) or Generalized Least Square (GLS) technique. GLS method is recommended when assumptions required by the OLS method (Heterocedasticity and autocorrelation) are not met. The advantage of using the Random Effect model is to eliminate Heterocedasticity and Autocorrelation. Multiple linear regression with the basic model are as follows:

$$
\text { Yit }=\alpha 0 t+\beta 1 X i t+\beta 2 X i t+\beta 3 X i t+e t
$$

The value of the regression coefficient here is crucial as the basis of the analysis, considering that this research uses a fundamental method. This means if the coefficient $\beta$ is positive $(+)$, then it can be said to occur in the direction of influence between independent variables with dependent variables. Any increase in the value of the independent variable will result in an increase in the dependent variable. Also, if the coefficient of value $\beta$ is negative $(-1)$, it indicates a negative effect in which the increase in the value of independent variable will decrease in the value of the dependent variable.

\section{Model Specifications}

This study uses panel data, which is a combination of time series data (time series) and crossdata (cross section). It uses three alternative estimation models. In estimating regression model, using panel data can be done through three approaches, among others:

\section{Common Effect Model (CEM)}

In this model, time and individual dimensions are not considered, so it is assumed that the behavior of corporate data is the same at various periods. This method uses the Ordinary Least Square (OLS) approach or the least squares technique to estimate the panel data model. The regression equation can be written as follows:

$$
Y=\alpha+\beta X_{i t}+e_{i t}
$$

For $i=1,2, \ldots, \mathrm{N}$ and $t=1,2, \ldots ., \mathrm{T}$, where $\mathrm{N}$ is the number of units / individuals cross section and $\mathrm{T}$ is the number of time periods. From the Common Effect Model, $\mathrm{N}+\mathrm{T}$ equations can be generated, that is, as many $\mathrm{T}$ equations as the cross section and as much as $\mathrm{N}$ time series equations can be generated.

\section{Fixed Effect Model (FEM)}

This model assumes that differences between individuals can be accommodated from different intercepts. To estimate Fixed Effects model, panel data using a dummy variable technique can be used to capture the difference between intercept companies. This estimation model is often also called the technique of Least Squares Dummy Variable (LSDV). The equation of this model is as follows:

$$
Y_{i t}=\alpha_{i o}+\beta_{1} X_{i t}+\beta_{2} X_{i t}+\beta_{3} X_{i t}+\beta_{4} d_{l i}+\beta_{5} d_{2 i}+e_{i t}
$$


The aio constants are now given subscripts, oi, $i$ denoting the object. Thus, each object has different constants. Duplicate variable $d$ for the first object and $o$ for the other object. The $d_{2 i}$ variable for the second object and $o$ for the other object.

\section{Random Effect Model (REM)}

In the Random Effect model, the difference between intercepts is accommodated by the error terms of each company. The advantage of using the Random Effect model is to eliminate heteroscedasticity. This model is also called the Error Component Model (ECM) or Generalized Least Square (GLS) technique. The equations used are similar to equations for fixed effects, except for different constants:

$$
Y i t=\alpha 0 t+\beta 1 X i t+\beta 2 X i t+\beta 3 X i t+e t
$$

Unlike the fixed effect model ( $\alpha 0$ is considered fixed), in this model $\alpha 0$ is assumed to be random, so it can be written in the equation:

$$
\alpha o=\alpha o+u i, i=1, \ldots, n
$$

In determining which panel regression model is appropriate for use, a chow-test and hausman test are performed. The chow-test is used to determine the common effect approach or fixed effect approach. While the hausman test is used to determine between fixed effect approach or random effect approach.

\section{Descriptive Statistics Analysis.}

\section{RESULTS AND DISCUSSION}

The final number of samples in this study is 51 companies with a 5 year period of observation, i.e. 2012-2016, so the number of observations in the research is as much as 254. Table 1 describes the descriptive statistical analysis of each variable used in the study, and it shows that CR has a mean of $249.15 \%$, with a maximum value of $3.092 .96 \%$, i.e. at PT. TSPC in 2012 . The high CRis due to the temporary placement of funds in the component of current assets at the end of the year. The mean value of DAR is 0.43 , meaning that the ratio of debt to the total assets of the manufacturing industry is relatively low, but there are companies that have a debt ratio far above the capital itself, amounting to 133\%, i.e at PT. ARGO in 2016.

The average earnings per share (EPS) of the manufacturing industry is Rp 498.35, with the maximum EPS occurring at PT. BRANDS of Rp 8,101.44, in 2014 and the lowest EPS (minimum) occurred at PT. ARGO amounted to -Rp1.124,20 in 2014. The total mean value of fixed assets of manufacturing companies amounted to Rp 2,980,694.00, with the highest total assets (maximum) at PT. ALTO of Rp60,444,610, - in 2016. Intangiable asset amounting to Rp113,454.60, with the highest intangible asset value (maximum) at PT. INDF amounting to Rp2,247,466.00 in 2013. Next is the mean net profit margin of $7.27 \%$, with the highest NPM (maximum) occurring at PT. INTP of $27.55 \%$ in 2012 , and the lowest occurred in PT. ARGO of $31.15 \%$ in 2016 . The mean value for PBV is 2.41 times, with the highest value (maximum) occurring at PT. HMSP as much as 27.35 times, and the lowest value occurred at PT. ARGO as much as -0.69 times in 2014. 
Tabel 1. Descriptive Statistics

\begin{tabular}{lcccccc}
\hline \multicolumn{1}{c}{ Mean } & Median & Maximum & Minimum & SD & Obs \\
\hline CR & 249.15 & 192.88 & $3,092.69$ & - & 231.42 & 253 \\
DAR & 0.43 & 0.41 & 1.33 & - & 0.19 & 253 \\
EPS & 498.35 & 87.22 & $8,101.44$ & $-1,124.20$ & $1,185.24$ & 253 \\
TANG & $2,980,694.00$ & $502,483.00$ & $60,444,610.00$ & - & $6,531,387.00$ & 253 \\
INTANG & $113,454.60$ & $3,768.00$ & $2,247,466.00$ & - & $282,876.20$ & 253 \\
NPM & 7.27 & 7.08 & 27.55 & -31.15 & 7.36 & 253 \\
PBV & 2.41 & 1.42 & 27.35 & -0.69 & 2.96 & 253 \\
PER & 47.25 & 15.23 & $2,887.75$ & -32.33 & 253.50 & 253 \\
Rt & 0.0469 & 0.0321 & 3.33 & -1.00 & 0.04 & 253 \\
ROA & 8.55 & 7.20 & 76.28 & -20.80 & 8.66 & 253 \\
SALES & $8,322,664.00$ & $1,837,251.00$ & $95,466,657.00$ & - & $16,477,283.00$ & 253 \\
\hline
\end{tabular}

\section{Notes:}

$\mathrm{CR}=$ Current Ratio, calculated Total Currrent Asset divided by Total Current Debt,

$\mathrm{DAR}=$ Total Debt to Total Asset, calculated amount of debt divided by total debt with total assets,

EPS= Earning per Share, calculated net profit after tax divided by the number of shares outstanding,

TANG= Tangible Asset, calculated the amount of tangible assets,

INTANG = Intangible Asset, calculated the amount of intangible assets,

NPM= Net Profit Margin, calculated net profit after tax divided by total net sales,

$\mathrm{PBV}=$ Price to Book Value, the price per share divided by the book value per share,

PER= Price Earning Ratio, calculated the price per share divided byearning per share,

Rit= Stock Return, calculated stock price $i$ period $t$ minus the stock price $i$ period $t-1$, divided by stock price $i$

period $t-1$,

ROA = Return on Asset, calculated net profit after tax divided by total assets,

SALES $=$ Total sales, the sum of the total net sales.

Variable PER has mean value (average) as much as 47.25 times, with maximum value occurring at PT. STAR of 2,887.75 times in 2015 and the lowest at PT. SMCB occurs as much as -32.33 times in 2015 and 2016. Furthermore, the stock return of manufacturing companies have a mean value of $4.69 \%$, with the highest share return of $333 \%$ at PT. BATA in year 2013 for ROA variable with mean value (mean) equal to $8.55 \%$, with highest ROA equal to $76.28 \%$ at PT. BREAD in 2016, and the lowest ROA (minimum) of $-20.80 \%$ at PT. ARGO in 2014. Finally, the mean value of sales variables worth Rp8,322,664, - with the highest selling rate of Rp95,466,657, -

\section{Regression Analysis Results}

This section presents the results of the regression analysis of the model used to explain the effect of investment on tangible and intangible assets against firm value. This study uses panel data, which is a combination of time series and cross-section data, the regression estimation method used common effects model (CEM), fixed effect model (FEM) and random effect model (REM). By using three alternative dependen variables for measure the firm performace are namely $\mathrm{ROA}, \mathrm{MBV}$, and Ri, only ROA is more approapriate in explaining the model, because the results of statistical analysis can explain th effects of independent variables toward dependent variable. Therefor, in this paper only regression model by using ROA as dependent variable is presented. 
Table 2. Results of Regression Estimation: (ROA, as dependent variable)

\begin{tabular}{lccc}
\hline & CEM & FEM & REM \\
\hline C & $-6.2551^{* * *}$ & $-0.9420^{* * *}$ & -0.7839 \\
DTANG & $(0.0011)$ & $(0.0049)$ & $(0.3492)$ \\
& $-0.7289^{* * *}$ & $-0.0000^{* *}$ & $-0.0525^{*}$ \\
DINTANG & $(0.0002)$ & $(0.0235)$ & $(0.0974)$ \\
& 0.0000 & 0.0020 & 0.0279 \\
LSALES & $(0.9294)$ & $(0.3585)$ & $(0.3011)$ \\
& $0.0283^{* * *}$ & -0.0138 & 0.0208 \\
DAR & $(0.0000)$ & $(0.1755)$ & $(0.1385)$ \\
& -0.0333 & $0.1280^{*}$ & 0.2082 \\
CR & $(0.4719)$ & $(0.0728)$ & $(0.1600)$ \\
& $0.0667^{* * *}$ & $0.0114^{* *}$ & $0.1107^{* * *}$ \\
EPS & $(0.0000)$ & $(0.0496)$ & $(0.0035)$ \\
& $0.1148^{* * *}$ & $0.5627^{* * *}$ & $0.2198^{* * *}$ \\
NPM & $(0.0000)$ & $(0.0000)$ & $(0.0023)$ \\
& $0.6826^{* * *}$ & $0.6528^{* * *}$ & $0.5118^{* * *}$ \\
PER & $(0.0000)$ & $(0.0001)$ & $(0.0093)$ \\
& -0.0048 & $0.0146^{* *}$ & 0.0169 \\
& $(0.5564)$ & $(0.0178)$ & $(0.2654)$ \\
\hline $\mathrm{R}^{2}$ & & & \\
F-stat & 0.8283 & 0.9716 & 0.5688 \\
& $116.96^{* * *}$ & $85.05^{* * *}$ & $31.99^{* * *}$ \\
DW & $(0.0000)$ & $(0.0000)$ & $(0.0000)$ \\
CHOW-test & 0.9856 & 1.9442 & 1.4997 \\
& & $18.20^{* * *}$ & \\
Hausman test & & $(0.0000)$ & $25.46^{* * *}$ \\
& & & $(0.0013)$ \\
\hline
\end{tabular}

\section{Notes:}

${ }^{*}$ coefficient is significant at the 0.10 level; ${ }^{* *}$ coefficient is significant at the 0.05 level; and *** coefficient is significant at the 0.01 .

From table 2 above, investment in tangible asset has a significant negative effect on firm value at various level of significance, that is, 0.01 in CEM, 0.05 on FEM, and 0.10 in REM. Furthermore, the three control variables, CR, EPS and NPM for the three models have a significant positive effect on firm value as measured by ROA as the dependent variable, while the LSALES variables only have a significant positive effect on firm value for CEM, and DAR and PER variables significantly influence firm value for FEM only. The value of $\mathrm{R}^{2}$ for the three models is high so that the ability of the variation of independent variables in explaining the dependent variable is very good, so it can be concluded that the model specification used is correct, and this is reinforced by the $F$-value of the three models which is significant at the 0.01 level. To determine which of the three estimation models is more appropriate or more accurate in explaining the variation in independent variables to the dependent variable, the second model of FEM is more appropriate. This is demonstrated by the results of the Chow-test and Hausman-tests that FEM is the best, yielding probability values of chow-test and hausman-test smaller than $0.05(0.000<0.05)$.

The estimation result states that only tangible asset variable has a significant negative effect on the firm's value. The results of this study support the previous research (Cao, 2015; Berk, et al., 1999; Carlson, et al., 2006), that investment in fixed assets negatively affect the short-term return of the company. This shows the fact that investors in the Indonesian capital market are mostly short-term oriented, that is their investment objectives for profit-taking is from such short-term trading activities. This fact, further explained, that for companies that invest fixed assets, it is usually necessary that funds or capital that is relatively large, can be obtained from 
both within and outside the company. Most companies prefer to use capital derived from the firm in the form of retained earnings, so there is tendency for public companies in Indonesia to try to hold their earnings as possible, because the retained earnings as a source of cheap funds. Thus, the opportunity for cash dividend payments is smaller, so for short-term investors, shares of companies investing in their fixed assets are released, which will result to a decline in corporate value. Furthermore, negative reactions may also discourage opportunistic behavior of managers in the form of investment empire building.

For other major variables, that is, investment of intangible assets (INTANG), it indicates that none of them affect the value of the company. This result conflicts with previous research, where investment returns on intangible assets, particularly investment in R\&D, have a positive and significant influence on firm value (Kumar and Li, 2016; Anderson and Garcia-Feijoo, 2006). This fact shows that in addition to the poor awareness of public companies in Indonesia to allocate funds for intangible asset investment (the development of products), also followed is the low appreciation of investors to the activity, so there is the tendency of public companies in Indonesia to still ignore investment in this asset.

\section{CONCLUSION AND RECOMMENDATION}

Based on the results of data analysis and discussion, the following conclusions and recommendations were drawn. This study was conducted to analyze the impact of the tangible and intangible assets investments on the value of 51 manufacturing companies listed on the Indonesia Stock Exchange during the period 2012-2016. Of the three models used in this study, only model 1 which is the ROA variable was used as the dependent variable to measure the value of manufacturing companies that are able to statistically explain variations between independent variables and the dependent variable.

The result of regression model shows that investment in tangible assets has a significant negative effect on the value of the manufacturing company. This indicates that such an investment impact leads to a decline in corporate value. The reason being that the capital expenditure, as a signaled by the company may not pay cash dividends because most of the profits will be used to invest in the assets. Thus, investors tend to sell off stocks of manufacturing firms and transfer them to stocks of companies in other sectors.

Of the three estimation models used, the FEM is more accurate in explaining the effect of tangible assets and intangible assets investments on the value of the manufacturing company. This is shown from the probability value of cho-test and hausman-test results which is smaller than $\alpha=0.05$. Thus, the characteristics of individual companies contribute in explaining the variation of independent variables to the dependent variable.The result of data analysis shows that investment in tangible asset has a significant negative influence on firm value, then in addition to company management, every investment decision on asset must be carefully considered to minimize negative impact on investment in tangible asset. Due to the negative impact on the company's value as a result of tangible asset investment, it is advisable for the company to minimize the investment of fixed assets with building empire investment motive.

Only one model was observed to be the best among the three models used to predict the effect of tangible assets and intangible assets investments on firm value. Thus, it is recommended in subsequent research to select another more appropriate variable, such as using Tobin's $Q$ variable, which represents the market value of debt and the company's equity and Economic Value Added (EVA), which uses the company's economic profit as its dependent variable. 


\section{References}

Anderson, CH, W., and Garcia-Feijoo, L. 2006. "Emperical evidence on capital investment, growth options, and security returns”, The Journal of Finance, 61(1), 171-194.

Berk, J.B., Green, R.C., and Naik, V. 1999. Optimal investment, growth options, and security returns," The Journal of Finance, 45, 1513-1607.

Cao, C., Simin, T., and Zhao. 2008. "Can growth options explain the trend in idiosyncratic risk", Review of Financial Studies, 21, 2599-2633.

Cao, S.S., 2015. Reexamining growth effects: Are all types of asset growth the same?, Contemporary Accounting Research, 33 (4), 1518-1548.

Carlson, M., Fisher, A., and Giammariono, R. 2006. “Coporate investment and asset prices dynamics: Implications for the cross-section of returns". The Journal of Finance, 61, 1009-1034.

Chauvin, Keith W., and Hirschey, Mark. 1993. Advertising, R\&D Expenditures and the Market Value of the Firm. Financial Management, 22(4), 128-140.

Chen, Ming-Chin., Cheng, Shu-Ju., and Hwang, Yuhchang. 2005. An Empirical Investigation of the Relationship between Intellectual Capital and Firm's market value and Financial Performance, Journal of Intellectual Capital, $6(2), 159-176$.

Cooper, Michael J., Gulen, Huseyin., and Schilkl, Michael J. 2008. Asset Growth and the Cross-Section of Stock Returns. The Journal of Finance, 63(4), 1609-1651.

Del Brio, Esther., De Miguel,Alberto., and Pindado, Julio. 2003. Investment and Firm Value: an analysis using panel data, Applied Financial Economics, 13(12), 913-923.

Durnev, Art., Morck, Randall., and Yeung, Bernard. 2004. Value-Enhancing Capital Budgeting and Firm-specific Stock Return Variation, The Journal of Finance, 59(1), 65-105.

Ehie, Ike C., and Olibe, Kingsley. 2010. The effect of R\&D investment on firm value: An examination of US manufacturing and service industries. International Journal of Production Economics, 128(1), 127-135.

Furman, J.L., Michael, E. P., and Scott, S. 2002. The determinant of national innovative capacity, Research Policy 31 , 53-81.

Galai, D., and Masulis, R.W. 1976. "The option pricing model and the risk factor of the stock", Journal of Financial Economics, 3, 53-81.

Gelb, David, S. 2002. Intangiable Assets and Firm's Disclosures: An Empirical Investigation, Journal of Business Finance \& Accounting, 29(3-4), 457-476.

Golec, Joseph., and Gupta, Neeraj J. 2014. Do investments in intangible customer assets affect firm value?. The Quarterly Review of Economics and Finance, 54(4), 513-520.

Johnson, Lewis D., and Pazderka, Bohumir. 1993. Firm Value and investment in R\&D. Managerial and Decision Economics, 14(1), 15-24.

Keown, A.J., Martin, J.D., Petty, J. W., and Scott, D.F, Jr. Financial Management: Principles and Applications, Tenth Edition, by. Pearson Education, Inc, New Jersey, 2005.

Kumar, P., and Li, D. 2016. “Capital Investment, innovative capacity, and stock returns,” The Journal of Finance, ， 2059-2094.

Lew, Sung Hee. 2015. Investment Expenditures and Firm Value; www. http://ssrn.com. Downloaded, 26 Oct 2017.

Li, D., and Lu, Z. 2010. “Does Q-theory with investment frisctions explain anomalies in the cross-section returns?", Journal of Financial Economics 98, 297-314.

Li, Erica X. N., Liu, Laura Xiaolei., and Xue, Chen. (2014). Intangible Assets and Cross- Sectional Stock Returns: Evidence from Structural Estimation, http://papers.ssrn.com. Quoted on 26 October 2017.

Marchica, Maria-Teresa., and Mura, Roberto, Financial Flexibility, Investment Ability, and Financial Value: Evidence from Firms with Spare Debt Capacity. Financial Management, 39(4), 1339-1365).

McConnell, John J., and Muscarella Chris J. 1985. Corporate Capital Expenditure Decisions and the Market Value of the Firm, Journal of Financial Economics, 14(3), 399-422.

Polk, Christopher., and Sapienza, Paolo, 2009. The Stock Market and Corporate Investment: A Test of Catering Theory, The Review of Financial Sudies, 22(1), 187-217. 
Reilly, Frank, K., and Brown, Keith, 2004. “Investment Analysis and Portfolio Management”. Seventh Edition, USA: South-Western.

Roger, M. 1998. The definition and measurement of innovation, Workinbg paper, University of Melbourne.

Tandelilin E. 2010. Portofolio dan Investasi, teori dan aplikasi. Edisi Pertama, Penerbit Kanisius, Yogyakarta.

Titman, S., Wei, J.K.C., and Xie, F. 2004. “Capital investment and stock returns”, Journal of Financial and Quantitative Analysis, 39, 677-700.

Trueman, Brett. 1986, The Relationship between the Level of Capital Expenditureand Firm Value, Journal of Financial and Quantitative Analysis, 21(2), 115-129. 